\title{
Evaluation of Hepatitis B Virus Nucleos(t)ide Analogues Resistance mutations in Treatment- Naiive Patients: A Systematic Review and Meta- Analysis
}

\author{
Alireza Mohebbi ( $\nabla$ mohebbi-a@goums.ac.ir) \\ 0003-2489-585X \\ Hesamaddin Shirzad-Aski \\ Golestan University of Medical Sciences and Health Services \\ Mohsen Ebrahimi \\ Golestan University of Medical Sciences and Health Services
}

Golestan University of Medical Sciences and Health Services Medical School https://orcid.org/0000-

\section{Research article}

Keywords: Hepatitis B virus, Treatment-naïve, Nucleos(t)ide analogue resistance mutations, DNA sequencing, quasispecies

Posted Date: December 17th, 2020

DOl: https://doi.org/10.21203/rs.3.rs-129066/v1

License: (c) (1) This work is licensed under a Creative Commons Attribution 4.0 International License.

Read Full License 


\section{Abstract}

Background: For detection of the nucleus(t)ide analog resistance (NAr) mutants among Hepatitis B virus (HBV) quasispecies, the selection of appropriate methodologies is necessary. Here, we aimed to investigate the role of different methods for the detection of NAr mutations among treatment-naïve patients with chronic HBV (CHB) infection.

Methods: In this systematic review and meta-analysis study, five databases were searched. Desired data were extracted from the selected studies. The $\mathrm{I}^{2}$ was used as an indicator of heterogeneity. The NAr mutations rate was investigated with a $95 \%$ confidence interval $(\mathrm{Cl})$.

Results: The overall ratio of occurrence of NAr within treatment-naïve CHB patients (14653) from 128 studies was $0.085(95 \% \mathrm{Cl}, 0.069-0.103, \mathrm{p}$-value $<0.0001)$. Direct sequencing was the most prevalent method of DNA sequencing (56.25\%). The rates of NAr mutations in the different methodologies, including the direct sequencing, InnoLipa, NGS, and PASS, were $0.079(0.037-0.160, p<0.0001), 0.058$ $(0.021-0.152, p<0.0001), 0.729(0.441-0.902, p=0.114)$, and $0.448(0.281-0.628, p=0.001)$, respectively.

Conclusions: Drug-resistant quasispecies of HBV exist in treatment-naïve patients in relatively high abundance. More sensitive methodologies like NGS should be used for detecting NAr fractions of the viral population. Replacement of current therapy with novel anti-HBV candidates also should be considered.

\section{Background}

Chronic Hepatitis B virus (HBV) is one of the main risk factors for cirrhosis, hepatocellular carcinoma (HCC), steatosis, and preterm birth in pregnant women [1, 2]. More than 300 million people are chronically infected worldwide with HBV, and nearly 1 million deaths occur annually due to HBV-related liver failure [3].

Current anti-HBV regimen comprised of interferon- $\mathrm{a}$ (IFN- $\mathrm{a}$ ) and HBV polymerase nucleos(t)ide analogs (NAs). Successful IFN-a therapy is only marginal and accompanied by various side effects. Besides, the efficiency of NAs is decreased and dampened by some point mutations, leading to the restoration of viral replication after completion of the treatment period. The next important obstacle for NA therapy is the pre-existence of NAr substitutions in treatment-naïve patients [4]. The rate of occurring resistance varies in different groups of patients and urgently needs an evaluation.

Under certain long-term NA therapy, the chance of emergence of new HBV quasispecies (QSs) increases. This is accompanied by a prolonged half-life (10-100 days) of hepatocyte resident viruses, a high rate of viral replication ( $10^{11}$ virion/day), the lack of polymerase proofreading [5], and the nature of the HBV overlapping genome. Therefore, the existence of a fractional population of QSs containing mutations, which reflects NAr is conceivable; even though those mutations resulted under endogenous or exogenous pressures. 
The complexity of QSs might be a good factor for distinguishing NA responders, as it correlates with the virological response [6]. Therefore, screening of HBV QSs' diversity is crucial to determine the antiviral therapy. Next-generation sequencing (NGS) platforms provide in-depth coverage, by which diagnosis of low-abundance viral QS is facilitated [7]. These platforms are distinct from conventional direct sequencing methods by their specific chemistry, accuracy, speed, cost, read length, and coverage. In this regard, ultra-deep pyrosequencing is more promising for the detection of viral QSs, compared to the conventional chain-termination Sanger sequencing [8]. For the first time, Han et al. have used the Illumina HiSeq 2000 sequencing system to assess HBV NAr mutations. They found that HiSeq 2000, in comparison with 3730 DNA analyzer, had better sensitivity and in-depth coverage for detection of HBV QS containing NAr mutations [9].

A systematic review and meta-analysis are necessary to figure out the existence of NAr mutations in treatment-naïve CHB patients. There has been a study, focused on the incidence of natural resistance mutations in naïve CHB patients, in 2015 [10]. Here, we have used the associated retrieved literature and extended it to the year 2018 from five databases. We further investigated the role of different methodologies in affecting the incidence of NAr mutations in CHB patients. The present study aims to update previous knowledge of mutation rate, among treatment-naïve CHB patients based on the existing methodologies. It was found that the high rate of mutations in the treatment-naïve HBV infected patients should not be neglected by using insensitive detection methods.

\section{Methods}

\subsection{Search strategy and terms}

We performed this systematic review and meta-analysis according to the Meta-Analysis of Observational Studies in Epidemiology consensus statement and Preferred Reporting Items for Systematic Reviews and Meta-Analyses (PRISMA). A comprehensive literature search of five electronic databases was conducted, including the Cochrane Library, Web of Science, PubMed, Google Scholar, and Crossref from December 31, 2013, to April 30, 2018. The used terms were as follows: (("Hepatitis B, chronic/virology"[MeSH Terms]) AND "treatment-naive"[Other Term]) OR "untreated"[Other Term] for PubMed and "Hepatitis B, chronic" in Title Abstract Keyword AND Treatment naive in Title Abstract Keyword OR Treatment-naive in Keyword AND "mutation" in Title Abstract Keyword with Cochrane Library publication date Between Dec 2013 and Apr 2018, in Cochrane Reviews, Cochrane Protocols, Trials, Clinical Answers, Editorials, Special collections (Word variations have been searched) for Cochrane library. Other databases searched with similar terms, according to the default search settings (Figure. 1).

PROSPERO database was screened for the probable protocol(s). Furthermore, additional relevant reports were investigated, using different types of grey literature such as meeting, poster, and oral and conference abstracts. In this regard and wherever needed, the expert people were contacted by email. Two key journals such as "Hepatology" and "Journal of Hepatology" were searched manually for the relevant reports. Reference lists of a previous systematic review and primary articles were also checked manually. 


\subsection{Eligibility criteria}

Studies published in English and/or English abstract were included, if they met the following criteria: the article reported the prevalence and rate of natural-occurring HBV reverse transcriptase mutations in $\mathrm{CHB}$ patients, with no history of anti-HBV therapeutics. Furthermore, the clear report of the method of NAr detection was another inclusion criterion. The exclusion criteria were having reports on the co-infection of HBV with Hepatitis C virus (HCV), Hepatitis D virus (HDV), and/or Human Immunodeficiency Virus (HIV), any pre-clinical or clinical studies of an intervention, and any review or other non-original/case-report papers.

\subsection{Study selection}

After removing the duplicates by using MS-Excel software, titles and/or abstracts of all articles were independently screened by two authors (AM and HS) for the relevant topic. Any disagreement (between two reviewers) was resolved through consensus or third author. After that, the full texts of the selected articles were evaluated and read by the two authors (AM and HS).

\subsection{The data extraction methods}

Two authors (AM and HS) analyzed the literature independently. The data were collected, using a standardized form. In case of disagreement, a third colleague was consulted. The extracted information was the first author's name, year of publication, country, the risk of bias assessment, methods of NAr detection, the number of treatment-naïve CHB patients, and the number of observed NAr resistance mutations in treatment-naïve CHB patients. Before dropping articles with incomplete information, an email was sent to the corresponding authors of studies for missing, unclear, and unreliable data.

\subsection{Quality assessment}

Two investigators (HS and NR) independently evaluated the quality of each included research. An 8-point scoring system was developed for this meta-analysis, based on the indicators of good-quality observational studies. The case number, sensitivity, and clarity of the methodologies for detection of mutation, and HBV markers, including HBeAg and viral load assessments, male/female ratio, sample types, and sampling collection date were adopted to assess the retrieved articles (Table 1). The maximum score of the quality assessment was 20 . Studies with an overall score of 17-20 were classified as excellent studies, and those that received an overall score of 14-16 were considered very good studies. Furthermore, a third group was comprised of studies with an overall score of 8-13. Discrepancies were settled by consensus. 
Table 1

Quality criteria for the included studies

\begin{tabular}{|c|c|c|}
\hline Characteristics & Criteria & Score $^{\dagger}$ \\
\hline \multirow[t]{2}{*}{ Sample size } & $\geq 100$ & 2 \\
\hline & $<100$ & 1 \\
\hline \multirow[t]{3}{*}{ Sensitivity of the methodologies } & Very High & 3 \\
\hline & High & 2 \\
\hline & Low & 1 \\
\hline \multirow[t]{5}{*}{ Sequencing methods } & MP-UDPS; UDPS; PASS; Illumina & 3 \\
\hline & MySeq; Clonal & \\
\hline & sequencing & \\
\hline & InnoLipa & 2 \\
\hline & Direct Sequencing & 1 \\
\hline \multirow[t]{2}{*}{ HBeAg status } & Known & 2 \\
\hline & Unknown & 1 \\
\hline \multirow[t]{2}{*}{ HBV viral load } & Known & 2 \\
\hline & Unknown & 1 \\
\hline \multirow[t]{3}{*}{ Gender (M/F ratio) } & $2 \geq ; 1: 1 ; \geq 0.7$ & 3 \\
\hline & $2<;<0.69$ & 2 \\
\hline & Unknown & 1 \\
\hline \multirow[t]{3}{*}{ Sample type } & Serum & 3 \\
\hline & Biopsy & 2 \\
\hline & Plasma & 1 \\
\hline \multirow[t]{2}{*}{ Sampling date } & Known & 2 \\
\hline & Unknown & 1 \\
\hline
\end{tabular}

\subsection{Statistical analysis}

After data were retrieved, statistical analysis was performed with the Comprehensive Meta-analysis Software V2 [11]. The type of the study was set as an estimate of means, proportions of rates in one group at one time-point. Effect size data entry format was set as two dichotomous, representing events 
and sample size in each category. This made us able to evaluate the overall occurrence of NAr incidence, among treatment-naïve $\mathrm{CHB}$ patients.

Random or Fixed Effect Models (R/FEMs) were used, based on the result of the methodological heterogeneity between the included studies. A forest plot was also constructed. $\mathrm{I}^{2}$ and Cochran's Q-value have evaluated for heterogeneity. $I^{2}$ more than $25 \%$ was an implication of heterogeneity. The source of heterogeneity was checked by sub-group analysis. The evidence rate was investigated with a $95 \%$ confidence interval $(\mathrm{Cl})$. Publication bias was also estimated through funnel plot and two Egger's and Begg's statistics. A P-value of less than 0.05 considered as significant.

\section{Results}

After the literature review, we came to 127 articles with suitable data. Among them, 106 articles were provided from previously published work by Zhang et al., 2015 and full text of them did not obtain. Further reports were retrieved from 2013 to 2018. Based on methodologies, one of the studies [12] has used two methods of NGS and direct sequencing, and to be more accurate in the analysis, it was considered as two studies. Accordingly, 128 studies assessed in this systematic review and metaanalysis. Data were extracted as explained above. The methodologies of NAr detection were only obtained from 32 studies. These methods were direct sequencing (18/32; 56.25\%), NGS (8/32; 25\%), InnoLipa $(5 / 32 ; 15.625 \%)$, and PASS $(1 / 32 ; 3.125 \%)$. The latter method was not included in the statistical analysis, as not enough study was found using the PASS method.

Heterogeneity was existed within the studies $\left(Q=1224.338 \mathrm{df}(127), \mathrm{I}^{2}=89.627, \mathrm{P}<0.0001\right)$. The REM results showed that the overall rate of HBV NAr mutations among treatment-naïve patients was 0.085 $(95 \% \mathrm{Cl}, 0.069-0.103, \mathrm{p}$-value $<0.0001)$. Both Egger's and Begg's tests showed publication bias $(-2.187 \pm$ $0.389 \mathrm{df}$ (126), $P<0.0001$ and $P=0.095$ ) (Figure.2).

To find out the reason for heterogeneity, we looked into the methods applied for the detection of NAr substitutions as a subgroup, within 32 studies (Table 2 ). The heterogeneity was observed within direct sequencing, NGS, and InnoLipa methods. Figure 3 shows the forest plot of the subgroups. 
Table 2

Random Effect Model evaluation of subgroup's effect sizes and heterogeneity in 30 studies

\begin{tabular}{|c|c|c|c|c|c|c|c|c|c|}
\hline \multirow{2}{*}{$\begin{array}{l}\text { Subgroups } \\
+\end{array}$} & \multirow{2}{*}{$\begin{array}{l}\text { Number } \\
\text { of } \\
\text { Studies } \\
\neq\end{array}$} & \multirow{2}{*}{$\begin{array}{l}\mathrm{NAr} / \\
\text { Patients }\end{array}$} & \multicolumn{3}{|c|}{ Effect size $(95 \% \mathrm{Cl})$} & \multicolumn{4}{|c|}{ Heterogeneity } \\
\hline & & & OR & $\begin{array}{l}\text { Lower } \\
\text { limit }\end{array}$ & $\begin{array}{l}\text { Upper } \\
\text { limit }\end{array}$ & Q-value & df & $\begin{array}{l}P \\
\text { value }\end{array}$ & $\left.\right|^{2}$ \\
\hline $\begin{array}{l}\text { Direct } \\
\text { sequencing }\end{array}$ & 18 & $257 / 3042$ & 0.079 & 0.037 & 0.160 & 397.639 & 17 & 0.000 & 95.725 \\
\hline NGS & 8 & $117 / 269$ & 0.729 & 0.441 & 0.902 & 62.536 & 7 & 0.000 & 88.806 \\
\hline InnoLipa & 5 & $282 / 1814$ & 0.058 & 0.021 & 0.152 & 80.406 & 4 & 0.000 & 95.025 \\
\hline PASS & 1 & $13 / 29$ & 0.448 & 0.281 & 0.628 & 0 & 0 & 1 & 0 \\
\hline
\end{tabular}

The results of direct sequencing showed an overall rate of 0.085 NAr mutations within treatment-naive patients with CHB. The minimum overall rate (0.003) was observed in the study of Xu et al., 2015 [13]. The maximum overall rate (0.833) was observed in the study of Pastor et al [14]. For the NGS method, the mean of the overall occurrence rate was 0.729 with the minimum and maximum of 0.163 and 0.982 , respectively.

A quality assessment was performed on 32 studies. Based on our scoring system, six, nineteen, and seven studies were categorized in excellent, very good, and good groups, respectively. As it is illustrated in Fig. 4, data of excellent studies have shown a NAr rate of 0.421 . The rate of NAr mutations was 0.132 for very good and 0.085 for good groups. As a validation of clustering, a Q-value between groups was assessed, which was 5.699 (df (2), P-value $=0.058)$.

\section{Discussion}

Life-long usage of NAs, pre-existing NAr mutations, toxicity, and cost of current anti-HBV treatments needs to be improved. The results of the current study showed a high rate of HBV NAr mutations among treatment-naïve patients. However, heterogeneity was observed within the studies. Therefore, a subgroup analysis was established to evaluate the role of studies' methodologies for the estimation of NAr mutations in the polymerase region. Hence, the role of different methodologies in the estimation of proportional QS containing NAr mutations is varied based on their sensitivities.

Evolution made HBV gain genetic instability [15], resulting in the establishment of QS containing viral fitting variants to ensure virus replication [5]. There are several methods for estimation of QS complexity, including DNA hybridization techniques, fluorescence, matrix-assisted laser desorption ionization-time of flight mass spectrometry (MALDI-TOF), oligonucleotide microarrays, flowthrough reverse dot-blot, PCR 
invader assay, PCR-Luminex assay [16], Inno-Lipa [17, 18], RFLP, Pyrosequencing [19], direct sequencing [20], Clonal-Sequencing [21], PASS [22], and Illumina M/HiSeq technologies [12, 23]. In comparison with the NGS, the conventional Sanger sequencing method has been shown to underestimate QS' mutants in a fraction of the pathogen population [24]. In this regard, subgroup analysis showed different rates of NAr incidence, among treatment-naïve CHB patients. Accordingly, the rate of NAr mutations detected by the NGS was higher than other techniques. According to the higher sensitivity of NGS technology, these data indicate a high rate of NAr mutations among treatment-naïve patients. Moreover, the rate of NAr in some studies w more than $80 \%$ within treatment-naïve patients. For the Inno-Lipa, the rate of NAr was 0.058 . More data are needed to further estimate the exact rate of NAr prevalence with the PASS method.

The sensitivity of various tests varies based on some technological differences. Direct sequencing is used as the most common method to identify viral QS when they are present in more than one-fifth of the HBV population $[9,25]$. The sensitivity of the line probe assay (LIPA) changes in the detection of viral QS from one genotype to others and should be optimized for every single mutation. PASS is a fluorescencebased real-time method with a sensitivity of $\sim 0.1 \%$, which is dependent on the reaction combination [8]. Clonal sequencing has not enough sensitivity for the detection of viral QS, because of its low coverage [26]. Furthermore, NGS methodologies like ultra-deep pyrosequencing (UDPS) are more sensitive (< $0.01 \%-1 \%)$ and accurate than direct sequencing and LIPA [25,27]. Overall, the selection of one sensitive method is crucial for detecting HBV QS. Ultra-deep pyrosequencing and Illumina M/HiSeq technologies provide the best in-depth insight into the QS population in a sample, which can be analyzed with the latest developments and approaches of bioinformatics.

The quality assessment of the retrieved studies was performed based on some factors. The importance of methodologies and their sensitivities in the detection of QS bearing NAr mutants have been discussed above. Further factors were viral load assay and HBeAg status. These factors provide essential information about virus activities in the infected cells. Accordingly, positive HBeAg in patients is an indication of active viral replication and increased the viral load. Taken together, these factors are correlated with a higher rate of viral mutations $[28,29]$. Some other factors were general, including sample size and normal distribution of male/female ratio, duration of sample collection, and sample types, which are the indicators of suitable study design. Based on these factors, literature was divided into three groups of excellent, very good and good groups. As a finding, the most contributing factor in the papers' quality assessment was the sensitivity of the detection method of NAr mutations. The excellent group was comprised of most of the studies with NGS methodology and showed higher rates of $\operatorname{NAr}(0.421)$ than very good $(0.134)$ and good $(0.085)$ groups.

For addressing the obstacle of QS for future HBV therapy and preventing the rapid evolution of the drugresistant viral genome, more attention should be paid to the replacement of current NA therapy. In this regard, we have previously overviewed potential approaches for functional anti-HBV therapy [4]. Furthermore, nucleic acid polymers are shown to have good anti-HBV potential in both pre-clinical and clinical stages [30-35]. Additionally, reactivation of immune responses in CHB patients is a rational cure for the disease, for which orally active Toll-like receptor 7 (TLR7) agonist, GS-9620 (Vesatolimod) is 
known to induce anti-HBV immune responses in animal models [36, 37]. Therefore, research on HBV treatment, including the discovery of novel anti-HBV agents and prescription of NAs should be according to the knowledge about NAr-contained QS among CHB patients.

\section{Conclusions}

NAr mutations exist among the most of treatment-naïve CHB patients. It was found that the high rate of mutations in the treatment-naïve patients should not be neglected by using insensitive detection methods like the Sanger sequencing, which is less efficient for the detection of rare HBV QS containing NAr. Therefore, utilization of HighTech sequencing technologies with higher accuracy and sensitivity is a promising approach for the detection of NAr mutations among treatment-naïve patients. This data also indicates that the prevalence of pre-existed NA-associated mutations is beyond using current conventional anti-HBV therapy and other therapeutic options should be taken into the account.

\section{Abbreviations}

Chronic Hepatitis B virus

HBV, Hepatocellular carcinoma:HCC, Interferon-a:IFN-a, Nucleos(t)ide analogues:NAs, NAs resistance:NAr, Lamivudine:LVD, Adefovir:ADV, Entecavir:ETV, Quasispecies:QS, Next-generation sequencing:NGS, Parallel allele-specific sequencing:PASS, The line probe assay:LIPA, Ultra-deep pyrosequencing:UDPS, Matrix Assisted Laser Desorption Ionization-time of Flight Mass Spectrometry:MALDI-TOF.

\section{Declarations}

Ethics approval and consent to participate: Not applicable.

Consent for publication: Not applicable.

Availability of data and materials: All data generated or analysed during this study are included in this published article.

Competing of interest disclosure: The authors declare that they have no competing interests.

Funding: Not applicable.

Authors' contributions: All authors have read and approved the manuscript

A.M: Conceptualization, Software, Investigation, Resources, Data Curation, Formal analysis, Writing Review \& Editing, Visualization, Project administration

H.S.A: Validation, Data Curation, Writing - Original Draft

M.E: Investigation, Writing - Original Draft, 
Acknowledgments: Not applicable.

\section{References}

1. Ma X, Sun D, Li C, Ying J, Yan Y. Chronic hepatitis B virus infection and preterm labor(birth) in pregnant women-an updated systematic review and meta-analysis. J Med Virol. 2018;90:93-100. doi:10.1002/jmv.24927.

2. Lesmana LA, Lesmana CR, Pakasi LS, Krisnuhoni E. Prevalence of hepatic steatosis in chronic hepatitis B patients and its association with disease severity. Acta Med Indones. 2012;44:35-9. http://www.ncbi.nlm.nih.gov/pubmed/22451183.

3. Howell J, Pedrana A, Cowie BC, Doyle J, Getahun A, Ward J, et al. Aiming for the elimination of viral hepatitis in Australia, New Zealand, and the Pacific Islands and Territories: Where are we now and barriers to meeting World Health Organization targets by 2030. J Gastroenterol Hepatol. 2019;34:408.

4. Mohebbi A, Lorestani N, Tahamtan A, Kargar NL, Tabarraei A. An overview of hepatitis B virus surface antigen secretion inhibitors. Front Microbiol. 2018;9 APR:1-9.

5. Sheldon J, Rodès B, Zoulim F, Bartholomeusz A, Soriano V. Mutations affecting the replication capacity of the hepatitis B virus. J Viral Hepatitis. 2006;13:427-34.

6. Liu F, Chen L, Yu DM, Deng L, Chen R, Jiang Y, et al. Evolutionary patterns of hepatitis B virus quasispecies under different selective pressures: Correlation with antiviral efficacy. Gut. 2011;60:1269-77.

7. Barzon L, Lavezzo E, Militello V, Toppo S, Palù G. Applications of next-generation sequencing technologies to diagnostic virology. Int J Mol Sci. 2011;12:7861-84.

8. Wang C, Mitsuya Y, Gharizadeh B, Ronaghi M, Shafer RW. Characterization of mutation spectra with ultra-deep pyrosequencing: Application to HIV-1 drug resistance. Genome Res. 2007;17:1195-201.

9. Han Y, Zhang Y, Mei Y, Wang Y, Liu T, Guan Y, et al. Analysis of hepatitis B virus genotyping and drug resistance gene mutations based on massively parallel sequencing. J Virol Methods. 2013;193:3417.

10. Zhang Q, Liao Y, Cai B, Li Y, Li L, Zhang J, et al. Incidence of natural resistance mutations in naïve chronic hepatitis B patients: A systematic review and meta-analysis. J Gastroenterol Hepatol. 2015;30:252-61.

11. Borenstein M, Hedges L, Higgins J, Rothstein H. Comprehensive meta-analysis version 2. Englewood, NJ Biostat. 2005;104.

12. Widasari DI, Yano Y, Heriyanto DS, Utsumi T, Yamani LN, Rinonce HT, et al. A deep-sequencing method detects drug-resistant mutations in the hepatitis B Virus in Indonesians. Intervirology. 2014;57:384-92.

13. Xu J, Wu B, Wang JH, Huang L, Wang DY, Zhao L, et al. Pre-existing mutations in reverse transcriptase of hepatitis B virus in treatment-naive chinese patients with chronic hepatitis B. PLoS 
One. 2015;10:e0117429.

14. Pastor R, Habersetzer F, Fafi-Kremer S, Doffoël M, Baumert TF, Gut JP, et al. Hepatitis B virus mutations potentially conferring adefovir/tenofovir resistance in treatment-naive patients. World $\mathrm{J}$ Gastroenterol. 2009;15:753-5.

15. Lauber C, Seitz S, Mattei S, Suh A, Beck J, Herstein J, et al. Deciphering the Origin and Evolution of Hepatitis B Viruses by Means of a Family of Non-enveloped Fish Viruses. Cell Host Microbe. 2017;22:387-99.e6.

16. Michailidis E, Kirby KA, Hachiya A, Yoo W, Hong SP, Kim SO, et al. Antiviral therapies: Focus on hepatitis B reverse transcriptase. Int J Biochem Cell Biol. 2012;44:1060-71.

17. Vutien P, Trinh HN, Garcia RT, Nguyen HA, Levitt BS, Nguyen K, et al. Mutations in HBV DNA Polymerase Associated With Nucleos(t)ide Resistance Are Rare in Treatment-naive Patients. Clin Gastroenterol Hepatol. 2014;12:1363-70.

18. Moehlen M, De Medina M, Hill M, Jeffers L, Schiff ER, Martin P. Absence of Hepatitis B Resistance Mutants before Introduction of Oral Antiviral Therapy. ISRN Hepatol. 2013;2013:1-5.

19. Salpini R, Svicher V, Cento V, Gori C, Bertoli A, Scopelliti F, et al. Characterization of drug-resistance mutations in HBV D-genotype chronically infected patients, naïve to antiviral drugs. Antiviral Res. 2011;92:382-5.

20. Nguyen MH, Garcia RT, Trinh HN, Nguyen HA, Nguyen KK, Nguyen LH, et al. Prevalence of hepatitis B virus DNA polymerase mutations in treatment-naïve patients with chronic hepatitis B. Aliment Pharmacol Ther. 2009;30:1150-8.

21. Coffin CS, Osiowy C, Gao S, Nishikawa S, Van Der Meer F, Van Marle G. Hepatitis B virus (HBV) variants fluctuate in paired plasma and peripheral blood mononuclear cells among patient cohorts during different chronic hepatitis B (CHB) disease phases. J Viral Hepat. 2015;22:416-26.

22. Ma J, Zhang Y, Chen X, Jin Y, Chen D, Wu Y, et al. Association of Preexisting Drug-Resistance Mutations and Treatment Failure in Hepatitis B Patients. PLoS One. 2013;8:e67606.

23. Munshi SU, Tran TTT, Vo TNT, Tabassum S, Sultana N, Nguyen TH, et al. Molecular characterization of hepatitis $B$ virus in Bangladesh reveals a highly recombinant population. PLoS One. 2017;12:e0188944.

24. Chan KH, To KKW, Chan BWK, Li CPY, Chiu SS, Yuen KY, et al. Comparison of pyrosequencing, sanger sequencing, and melting curve analysis for detection of low-frequency macrolide-resistant Mycoplasma pneumoniae quasispecies in respiratory specimens. J Clin Microbiol. 2013;51:2592-8.

25. Solmone M, Vincenti D, Prosperi MCF, Bruselles A, Ippolito G, Capobianchi MR. Use of Massively Parallel Ultradeep Pyrosequencing To Characterize the Genetic Diversity of Hepatitis B Virus in DrugResistant and Drug-Naive Patients and To Detect Minor Variants in Reverse Transcriptase and Hepatitis B S Antigen. J Virol. 2009;83:1718-26.

26. Wu NC, De La Cruz J, Al-Mawsawi LQ, Olson CA, Qi H, Luan HH, et al. HIV-1 quasispecies delineation by tag linkage deep sequencing. PLoS One. 2014;9. 
27. Macalalad AR, Zody MC, Charlebois P, Lennon NJ, Newman RM, Malboeuf CM, et al. Highly sensitive and specific detection of rare variants in mixed viral populations from massively parallel sequence data. PLoS Comput Biol. 2012;8.

28. Parizad EG, Parizad EG, Khosravi A, Amraei M, Valizadeh A, Davoudian A. Comparing HBV viral load in serum, Cerumen, and saliva and correlation with $\mathrm{HBeAg}$ serum status in patients with chronic hepatitis B infection. Hepat Mon. 2016;16.

29. Ghabeshi S, Sharifi Z, Hosseini SM, Mahmoodian Shooshtari M. Correlation between viral load of hbv in chronic hepatitis b patients and precore and basal core promoter mutations. Hepat Mon. 2013;13.

30. Vaillant A. Nucleic acid polymers: Broad spectrum antiviral activity, antiviral mechanisms and optimization for the treatment of hepatitis B and hepatitis D infection. Antiviral Res. 2016;133:3240.

31. Roehl I, Seiffert S, Brikh C, Quinet J, Jamard C, Dorfler N, et al. Nucleic Acid Polymers with Accelerated Plasma and Tissue Clearance for Chronic Hepatitis B Therapy. Mol Ther - Nucleic Acids. 2017;8:1-12.

32. Schöneweis K, Motter N, Roppert PL, Lu M, Wang B, Roehl I, et al. Activity of nucleic acid polymers in rodent models of HBV infection. Antiviral Res. 2018;149:26-33.

33. Real Cl, Werner M, Paul A, Gerken G, Schlaak JF, Vaillant A, et al. Nucleic acid-based polymers effective against hepatitis B Virus infection in patients don't harbor immunostimulatory properties in primary isolated liver cells. Sci Rep. 2017;7:43838. doi:10.1038/srep43838.

34. Noordeen F, Vaillant A, Jilbert AR. Nucleic acid polymers prevent the establishment of duck hepatitis B virus infection in vivo. Antimicrob Agents Chemother. 2013;57:5299-306.

35. Beilstein F, Blanchet M, Vaillant A, Sureau C. Nucleic acid polymers are active against Hepatitis Delta Virus infection in vitro. J Virol. 2017;92:JVI.01416-17.

36. Lanford RE, Guerra B, Chavez D, Giavedoni L, Hodara VL, Brasky KM, et al. GS-9620, an oral agonist of toll-like receptor-7, induces prolonged suppression of hepatitis $B$ virus in chronically infected chimpanzees. Gastroenterology. 2013;144.

37. Menne S, Tumas DB, Liu KH, Thampi L, Aldeghaither D, Baldwin BH, et al. Sustained efficacy and seroconversion with the toll-like receptor 7 agonist GS-9620 in the woodchuck model of chronic hepatitis B. J Hepatol. 2015;62:1237-45.

\section{Figures}




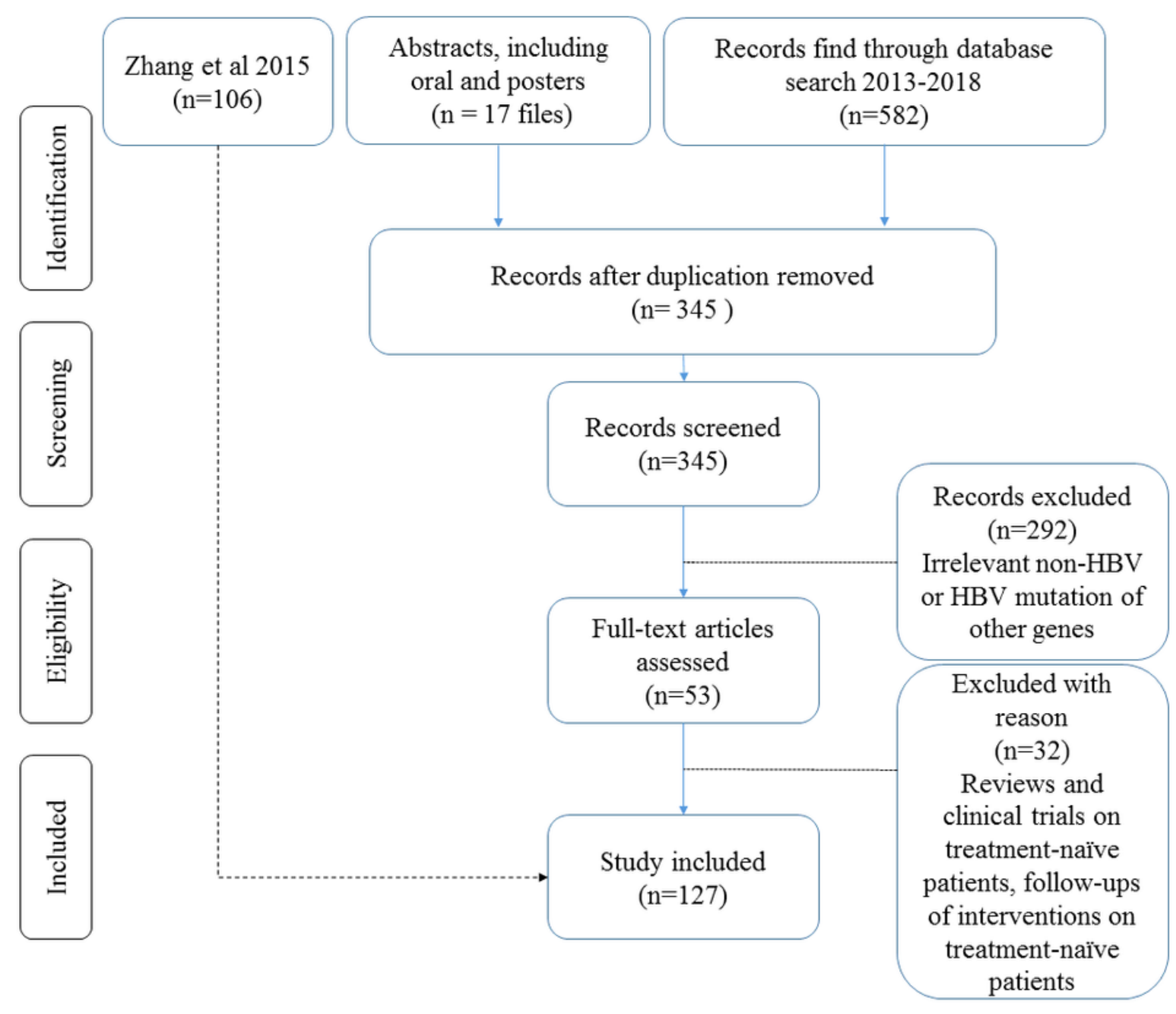

\section{Figure 1}

PRISMA table. One hundred and twenty-seven studies were retrieved, of which 1 was divided into 2 studies based on different methodologies. 


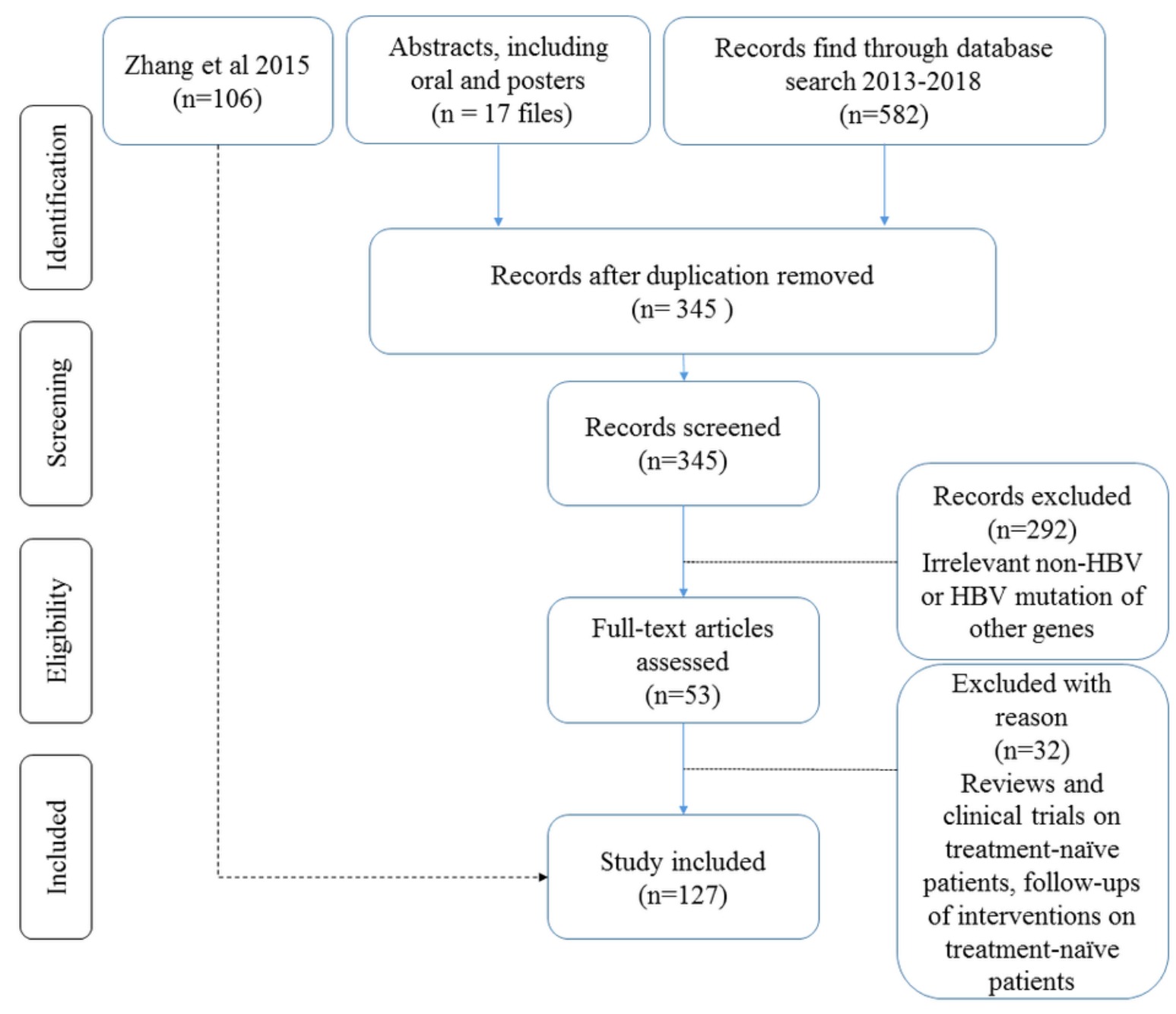

\section{Figure 1}

PRISMA table. One hundred and twenty-seven studies were retrieved, of which 1 was divided into 2 studies based on different methodologies. 
Funnel Plot of Standard Frror by Logit event rate

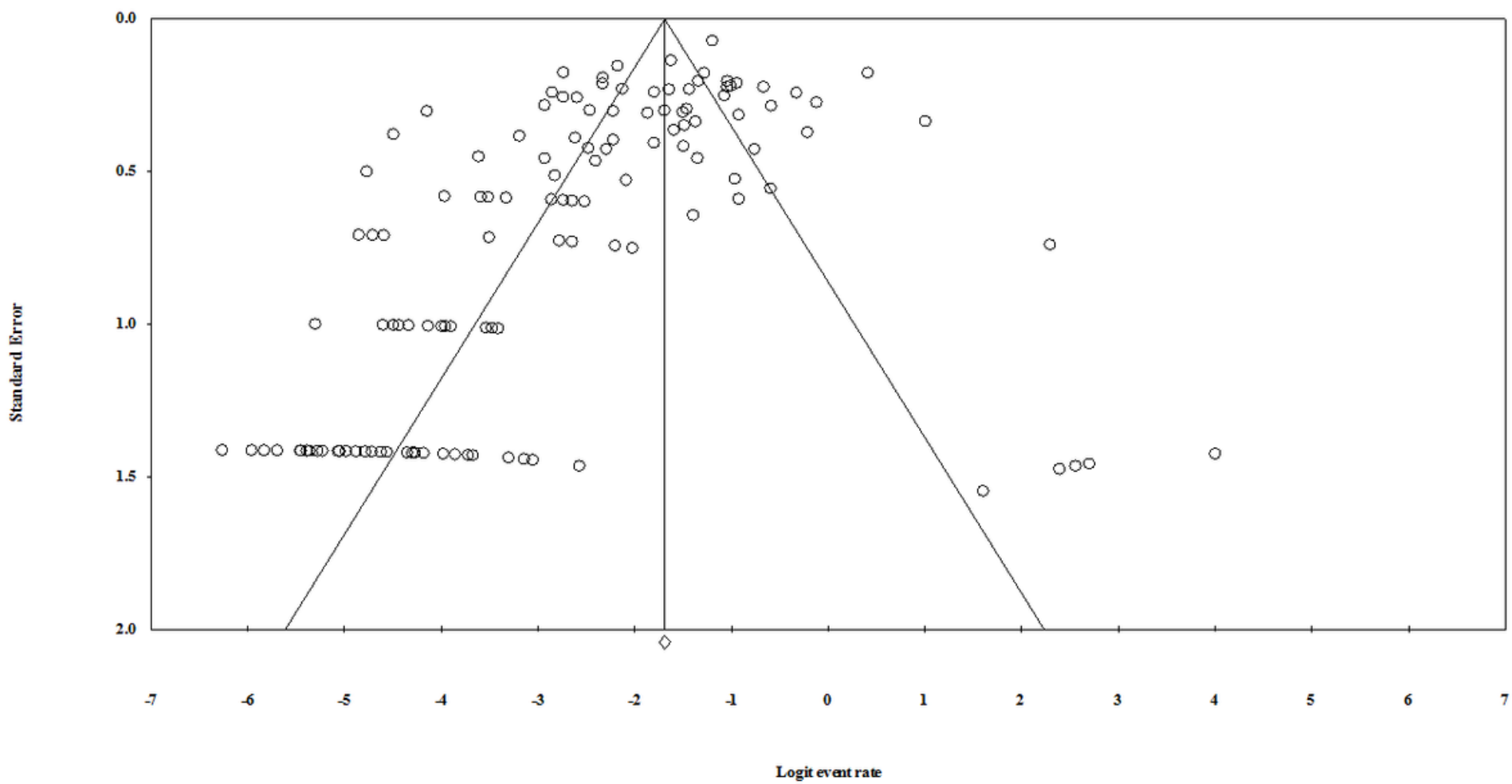

\section{Figure 2}

Funnel plot of publication bias within studies retrieved for statistical analyzes. The plot shows the asymmetric distribution of data and publication bias.

Funnel Plot of Standard Error by Logit event rate

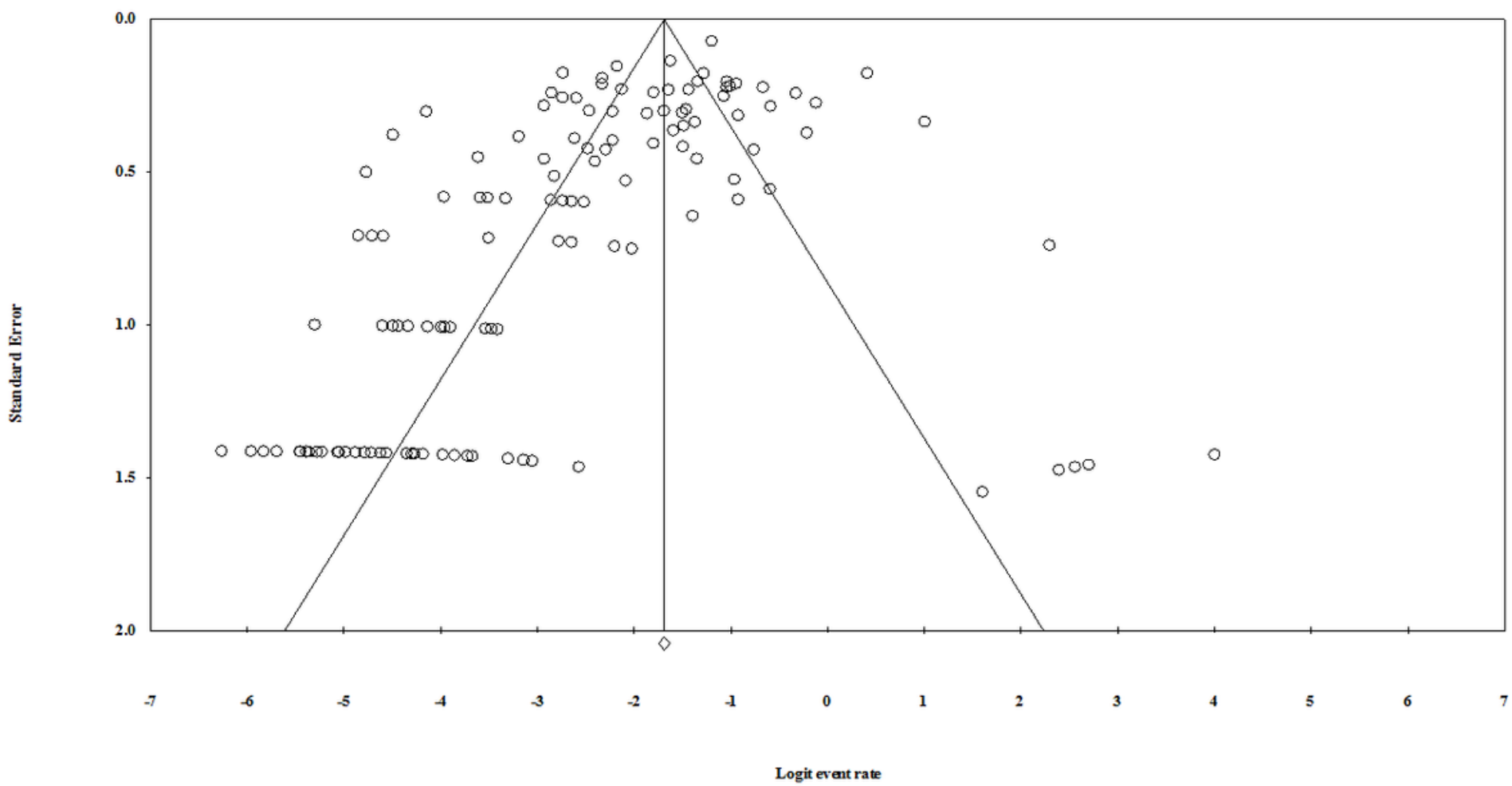


Figure 2

Funnel plot of publication bias within studies retrieved for statistical analyzes. The plot shows the asymmetric distribution of data and publication bias.

\begin{tabular}{|c|c|}
\hline$\frac{\text { Group tw }}{\text { Sulberoup within stucty }}$ & Sunk name \\
\hline Direct-Seq & Xuet al 2015 \\
\hline Direct-Seq & Ismail AM2010 \\
\hline Direct-Seq & Nguryen MH 2009 \\
\hline Direct-Seq & Panigrahi R 2013 \\
\hline Direct-Seq & Gomes-Gouvea et al 2015 \\
\hline Direct-Seq & Pacheco et al 2017 \\
\hline Direct-Seq & Jardi R 2007 \\
\hline Direct-Seq & Lik:Yuen Chan et al 2007 \\
\hline Direct-Seq & Han Y 2009 \\
\hline Direct-Seq & Widasari et al 2014 \\
\hline Direct-Seq & Malabadi M 2013 \\
\hline Direct-Seq & Singh B 2013 \\
\hline Direct-Seq & Salpini etal 2011 \\
\hline Direct-Seq & Sayan et al 2010 \\
\hline Direct-Seq & Mestafa ALTIND? et al 2016 \\
\hline Direct-Seq & Singh et al 2015 \\
\hline Direct-Seq & Kim et al 2017 \\
\hline Direct-Seq & Pastor et al 2009 \\
\hline \multicolumn{2}{|l|}{ Direct-Seq } \\
\hline InnoLiPA & Mochlen et al 2013 \\
\hline InnoLiPA & Vutien P 2013 \\
\hline InnoLPA & Mrandola et al 2011 \\
\hline InnoLiPA & Zhao Y et al 2016 \\
\hline InnoLPA & $\operatorname{Tan} 2012$ \\
\hline \multicolumn{2}{|l|}{ InnoLPA } \\
\hline Nas & Bui et al 2017 \\
\hline Nas & Nishij ima N 2012 \\
\hline NGS & Marnhi et al 2017 \\
\hline Nas & Coffin et al 2014 \\
\hline Nas & Solmone et al 2009 \\
\hline Nas & Widasariet al 2014 \\
\hline Nas & WASTYASTUTI et al 2016 \\
\hline Nas & Gaoet al 2017 \\
\hline \multicolumn{2}{|l|}{ NGS } \\
\hline PASS & Ma et al 2013 \\
\hline PASS & \\
\hline Oherall & \\
\hline
\end{tabular}

\begin{tabular}{|c|c|c|c|c|c|}
\hline \multirow[t]{2}{*}{ Sthroenp within studv } & \multicolumn{4}{|c|}{ Statistics for each sturty } & \multirow[b]{2}{*}{ p. Vahe } \\
\hline & $\begin{array}{c}\text { Event } \\
\text { rate }\end{array}$ & $\begin{array}{c}\text { Lower } \\
\text { limit }\end{array}$ & $\begin{array}{l}\text { Upper } \\
\text { limit }\end{array}$ & Z Value & \\
\hline Direct-Seq & 0.003 & 0.000 & 0.045 & -4.109 & 0.000 \\
\hline Direct-Seq & 0.005 & 0.000 & 0.076 & -3.719 & 0.000 \\
\hline Direct-Seq & 0.008 & 0.003 & 0.022 & -9.484 & 0.000 \\
\hline Direet-Seq & 0.009 & 0.001 & 0.127 & -3.315 & 0.001 \\
\hline Direct-Seq & 0.016 & 0.009 & 0.028 & -13.624 & 0.000 \\
\hline Direct-Seq & 0.026 & 0.011 & 0.062 & -7.955 & 0.000 \\
\hline Direct Seq & 0.027 & 0.009 & 0.080 & -6.122 & 0.000 \\
\hline Direct-Seq & 0.029 & 0.004 & 0.177 & -3.476 & 0.001 \\
\hline Direct-Seq & 0.055 & 0.035 & 0.085 & -11.739 & 0.000 \\
\hline Direct-Seq & 0.071 & 0.004 & 0.577 & -1.748 & 0.081 \\
\hline Direct-Seq & 0.089 & 0.063 & 0.125 & -11.939 & 0.000 \\
\hline Direct-Seq & 0.099 & 0.048 & 0.193 & -5.559 & 0.000 \\
\hline Direct-Seq & 0.143 & 0.094 & 0.211 & -7.419 & 0.000 \\
\hline Direct-Seq & 0.341 & 0.250 & 0.416 & -2.931 & 0.003 \\
\hline Direct-Seq & 0.358 & 0.242 & 0.495 & -2.032 & 0.012 \\
\hline Direct-Seq & 0.420 & 0.310 & 0.539 & -1.319 & 0.187 \\
\hline Direct-Seq & 0.603 & 0.517 & 0.683 & 2.342 & 0.019 \\
\hline \multirow{2}{*}{ Direct-Seq } & 0.833 & 0.194 & 0.990 & 1.039 & 0.299 \\
\hline & 0.079 & 0.037 & 0.160 & -6.029 & 0.000 \\
\hline ImoLiPA & 0.010 & 0.001 & 0.138 & -3.247 & 0.001 \\
\hline ImoLiPA & 0.010 & 0.003 & 0.039 & -6.451 & 0.000 \\
\hline ImoLiPA & 0.051 & 0.030 & 0.086 & -10.270 & 0.000 \\
\hline IrnoLiPA & 0.089 & 0.061 & 0.130 & -10.862 & 0.000 \\
\hline \multirow[t]{2}{*}{ ImnoLiPA } & 0.233 & 0.209 & 0.260 & -16.248 & 0.000 \\
\hline & 0.058 & 0.021 & 0.152 & -5.111 & 0.000 \\
\hline NGS & 0.163 & 0.110 & 0.235 & -7.022 & 0.000 \\
\hline NGS & 0.357 & 0.157 & 0.624 & -1.054 & 0.292 \\
\hline NGS & 0.472 & 0.312 & 0.605 & -0.412 & 0.680 \\
\hline NGS & 0.909 & 0.700 & 0.977 & 3.105 & 0.002 \\
\hline NGS & 0917 & 0.378 & 0.995 & 1.623 & 0.105 \\
\hline NGS & 0929 & 0.423 & 0.996 & 1.748 & 0.081 \\
\hline Nas & 0.938 & 0.461 & 0.996 & 1.854 & 0.064 \\
\hline \multirow[t]{2}{*}{ Nas } & 0.982 & 0.770 & 0.999 & 2.808 & 0.005 \\
\hline & 0.729 & 0.441 & 0.902 & 1.580 & 0.114 \\
\hline \multirow[t]{3}{*}{ PASS } & 0.448 & 0.281 & 0.628 & -0.556 & 0.578 \\
\hline & 0.448 & 0.281 & 0.628 & -0.536 & 0.578 \\
\hline & 0.229 & 0.160 & 0318 & -5.291 & 0.000 \\
\hline
\end{tabular}

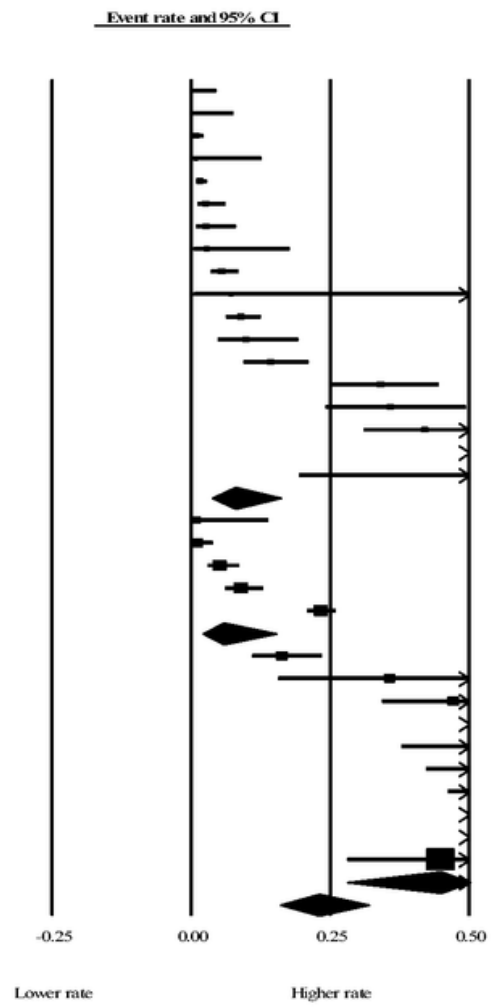

Figure 3

Forest plot analysis of the studies. Data show more rate of NAr mutations in CHB patients based on highsensitive methods like NGS. 


\begin{tabular}{|c|c|c|c|c|c|c|c|}
\hline Grouple & Stukt name & Sitgromp within stuktv & & Statis & thes for e: & chsturty & \\
\hline Sulvgroup within study & & & $\begin{array}{c}\text { Event } \\
\text { rate }\end{array}$ & $\begin{array}{c}\text { Lower } \\
\text { limit }\end{array}$ & $\begin{array}{l}\text { Uppper } \\
\text { limit }\end{array}$ & ZValue & p. Value \\
\hline Direct-Seq & Xuet al 2015 & Direct-Seq & 0.003 & 0.000 & 0.045 & -4.109 & 0.000 \\
\hline Direct-Seq & Ismail AM 2010 & Direct-Seq & 0.005 & 0.000 & 0.076 & -3.719 & 0.000 \\
\hline Direct-Seq & Ngrayen MH 2009 & Direct-Seq & 0.008 & 0.003 & 0.022 & -9.484 & 0.000 \\
\hline Direct-Seq & Panigrahi R 2013 & Direct-Seq & 0.009 & 0.001 & 0.127 & -3.315 & 0.001 \\
\hline Direct-Seq & Gomes-Gouvea et al 2015 & Direct-Soq & 0.016 & 0.009 & 0.028 & -13.624 & 0.000 \\
\hline Direct-Seq & Pachecoet al 2017 & Direct-Seq & 0.026 & 0.011 & 0.062 & -7.955 & 0.000 \\
\hline Direct-Seq & Jardi R 2007 & Direct Seq & 0.027 & 0.009 & 0.080 & -6.122 & 0.000 \\
\hline Direct-Seq & Lik Yuen Chan et al 2007 & Direct Seq & 0.029 & 0.004 & 0.177 & -3.476 & 0.001 \\
\hline Direct-Seq & Han Y 2009 & Direct-Seq & 0.055 & 0.035 & 0.085 & -11.739 & 0.000 \\
\hline Direct-Seq & Widasari et al 2014 & Direct-Seq & 0.071 & 0.004 & 0.577 & -1.748 & 0.081 \\
\hline Direct-Seq & Mahabadi M 2013 & Direct-Seq & 0.089 & 0.063 & 0.125 & -11.939 & 0.000 \\
\hline Direct-Seq & Singh B 2013 & Direct-Seq & 0.099 & 0.048 & 0.193 & -5.559 & 0.000 \\
\hline Direct-Seq & Salpini et al 2011 & Direct Seq & 0.143 & 0.094 & 0.211 & -7.419 & 0.000 \\
\hline Direct-Seq & Sayan et al 2010 & Direct Seq & 0.341 & 0.250 & 0.446 & -2.931 & 0.003 \\
\hline Direct-Seq & Mestafa ALTIND? et al 2016 & Direct-Seq & 0.358 & 0.242 & 0.495 & -2.032 & 0.042 \\
\hline Direct-Seq & Singla et al 2015 & Direct-Seq & 0.420 & 0.310 & 0.539 & -1.319 & 0.187 \\
\hline Direct-Seq & Kim et al 2017 & Direct-Seq & 0.603 & 0.517 & 0.683 & 2.342 & 0.019 \\
\hline Direct-Seq & Pastor et al 2009 & Direct-Seq & 0.833 & 0.194 & 0.990 & 1.039 & 0.299 \\
\hline Direct-Seq & & & 0.079 & 0.037 & 0.160 & -6.029 & 0.000 \\
\hline InnoLiPA & Moehlen et al 2013 & ImoLiPA & 0.010 & 0.001 & 0.138 & -3.247 & 0.001 \\
\hline InnoLiPA & Vutien P 2013 & ImoLiPA & 0.010 & 0.003 & 0.039 & -6.451 & 0.000 \\
\hline InnoLiPA & Mirandola et al 2011 & ImoLiPA & 0.051 & 0.030 & 0.086 & -10.270 & 0.000 \\
\hline InnoLiPA & Zhao Y et al 2016 & InnoLiPA & 0.089 & 0.061 & 0.130 & -10.862 & 0.000 \\
\hline InnoLiPA & $\operatorname{Tan} 2012$ & ImnoLiPA & 0.233 & 0.209 & 0.260 & -16.248 & 0.000 \\
\hline InnoLiPA & & & 0.058 & 0.021 & 0.152 & -5.111 & 0.000 \\
\hline Nas & Bui et al 2017 & Nas & 0.163 & 0.110 & 0.235 & -7.022 & 0.000 \\
\hline Nas & Nishij ima N 2012 & Nas & 0.357 & 0.157 & 0.624 & -1.054 & 0.292 \\
\hline Nas & Murnhi et al 2017 & Nas & 0.472 & 0.342 & 0.605 & -0.412 & 0.680 \\
\hline NaS & Coffin et al 2014 & NaS & 0.909 & 0.700 & 0.977 & 3.105 & 0.002 \\
\hline Nas & Solmone et al 2009 & NGS & 0.917 & 0.378 & 0.995 & 1.623 & 0.105 \\
\hline Nas & Widasari et al 2014 & Nas & 0.929 & 0.423 & 0.996 & 1.748 & 0.081 \\
\hline NaS & WASTYASTUTI et al 2016 & NaS & 0.938 & 0.461 & 0.996 & 1.854 & 0.064 \\
\hline Nas & Gaoet al 2017 & Nas & 0.982 & 0.770 & 0.999 & 2.808 & 0.005 \\
\hline Nas & & & 0.729 & 0.441 & 0.902 & 1.580 & 0.114 \\
\hline PASS & Ma et al 2013 & PASS & 0.448 & 0.281 & 0.628 & -0.556 & 0.578 \\
\hline PASS & & & 0.448 & 0.281 & 0.628 & -0.556 & 0.578 \\
\hline Overall & & & 0.229 & 0.160 & 0.318 & -5.291 & 0.000 \\
\hline
\end{tabular}

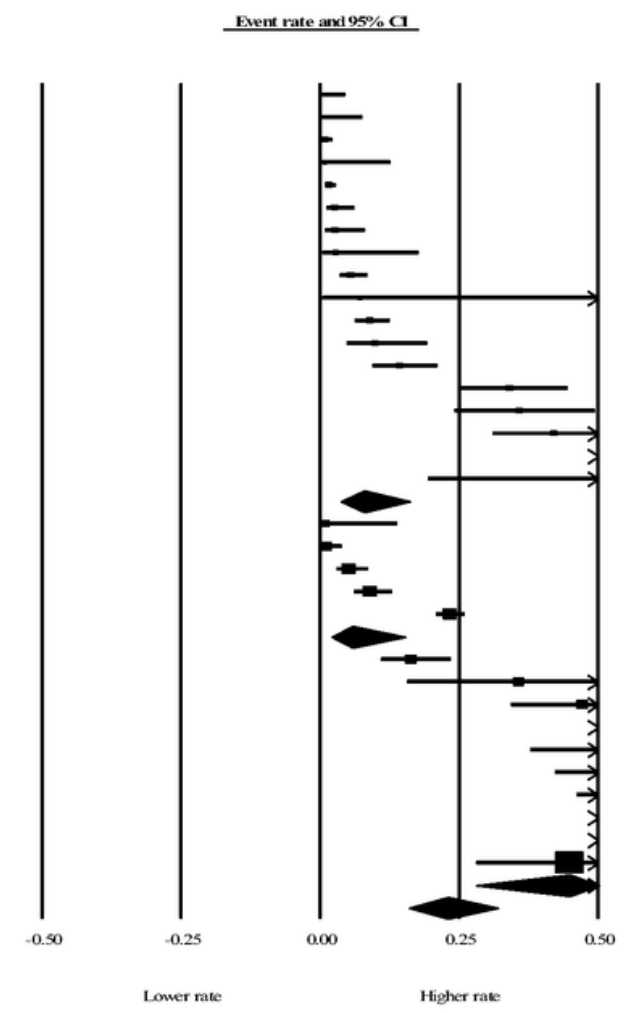

Figure 4

Forest plot analysis of the studies. Data show more rate of NAr mutations in CHB patients based on highsensitive methods like NGS. 


Groupby
Sulgroup willin
Excellent
Excellent
Excellent
Excellent
Excellent
Excellent
Excellent
Good
Good
Good
Good
Good
Good
Good
Good
Very Good
Very Good
Very Good
Very Good
Very Good
Very Good
Very Good
Very Good
Very Good
Very Good
Very Good
Very Good
Very Good
Very Good
Very Good
Very Good
Very Good
Very Good
Very Good
Very Good
Overall

$\underline{\text { Suck name }}$

Bui et al 2017

Coffinet al 2014

Gao et al 2017

Ma et al 2013

Munshi et al 2017

Vutien P 2013

Jarct R 2007

Lik-Yuen Chan et al 2007

Panigrahi R 2013

Salpini et al 2011

Singla B 2013

Singla et al 2015

Widasari et al 2014

Widasari et al 2014

Gomes-Gouvea et al 2015

Han Y 2009

Ismail AM 2010

Kim et al 2017

Mahabadi M 2013

Mirandola et al 2011

Moehlen et al 2013

Musafa ALTIND? et al 2016

Ngryen MH 2009

Nishij ima N 2012

Pachecoet al 2017

Pastor et al 2009

Sayanet al 2010

Solmone et al 2009

Tan 2012

WASTYYASTUT1 et al 2016

Xuet al 2015

Zhno Y et al 2016
Score

Comparison

Excellent NCS

Excellent NGS

Excellent NGS

Excellent PASS

Excellent NGS

Excellent ImoLipa

Good Direct Seq

Good Direct Seq

Good Direct Seq

Good Direct Seq

Good Direct Seq

Good Direct Seq

Good Direct Seq

Very Good NGS

Very Good Direct Seq

Very Good Direct Seq

Very Good Direct Seq

Very Good Direct Seq

Very Good Direct Seq

Very Good ImoLipa

Very Good InoLipa

Very Good Direct Seq

Very Good Direct Seq

Very Good NGS

Very Good Direct Seq

Very Good Direct Seq

Very Good Direct Seq

Very Good NGS

Very Good ImoLipa

Very Good NGS

Very Good Direct Seq

Very Good Inolipa \begin{tabular}{ccr} 
& \multicolumn{2}{c}{ Statistics for each stuty } \\
Event & Lower Upper & \\
rate & limit limit Z-Value & p-Value
\end{tabular}

$\begin{array}{lllll}0.163 & 0.110 & 0.235 & -7.022 & 0.000\end{array}$

$\begin{array}{lllll}0.909 & 0.700 & 0.977 & 3.105 & 0.002\end{array}$

$\begin{array}{lllll}0.982 & 0.770 & 0.999 & 2.808 & 0.005\end{array}$

$\begin{array}{lllll}0.448 & 0.281 & 0.628 & -0.556 & 0.578\end{array}$

$\begin{array}{lllll}0.472 & 0.342 & 0.605 & -0.412 & 0.690\end{array}$

$\begin{array}{lllll}0.010 & 0.003 & 0.039 & -6.451 & 0.000\end{array}$

$\begin{array}{lllll}0.421 & 0.156 & 0.740 & -0.460 & 0.646\end{array}$

$\begin{array}{lllll}0.027 & 0.009 & 0.050 & -6.122 & 0.000\end{array}$

$\begin{array}{lllll}0.029 & 0.004 & 0.177 & -3.476 & 0.001\end{array}$

$\begin{array}{lllll}0.009 & 0.001 & 0.127 & -3.315 & 0.001\end{array}$

$\begin{array}{lllll}0.143 & 0.094 & 0.211 & -7.419 & 0.000\end{array}$

$\begin{array}{lllll}0.099 & 0.048 & 0.193 & -5.559 & 0.000\end{array}$

$\begin{array}{lllll}0.420 & 0.310 & 0.539 & -1.319 & 0.187\end{array}$

$\begin{array}{lllll}0.071 & 0.004 & 0.577 & -1.748 & 0.081\end{array}$

$\begin{array}{lllll}0.085 & 0.032 & 0.209 & -4.467 & 0.000\end{array}$

$\begin{array}{lllll}0.929 & 0.423 & 0.996 & 1.748 & 0.081\end{array}$

$\begin{array}{lllll}0.016 & 0.009 & 0.028 & -13.624 & 0.000\end{array}$

$\begin{array}{lllll}0.055 & 0.035 & 0.085 & -11.739 & 0.000\end{array}$

$\begin{array}{lllll}0.005 & 0.000 & 0.076 & -3.719 & 0.000\end{array}$

$\begin{array}{lllll}0.603 & 0.517 & 0.683 & 2.342 & 0.019\end{array}$

$\begin{array}{lllll}0.089 & 0.063 & 0.125 & -11.939 & 0.000\end{array}$

$\begin{array}{llll}0.051 & 0.030 & 0.086 & -10.220\end{array}-0.000$

$\begin{array}{lllll}0.010 & 0.001 & 0.138 & -3.247 & 0.001\end{array}$

$\begin{array}{lllll}0.358 & 0.242 & 0.495 & -2.032 & 0.042\end{array}$

$\begin{array}{lllll}0.008 & 0.003 & 0.022 & -9.484 & 0.000\end{array}$

$\begin{array}{llllll}0.357 & 0.157 & 0.624 & -1.054 & 0.292\end{array}$

$\begin{array}{lllll}0.026 & 0.011 & 0.062 & -7.955 & 0.000\end{array}$

$\begin{array}{lllll}0.833 & 0.194 & 0.990 & 1.039 & 0.299\end{array}$

$\begin{array}{lllll}0.341 & 0.250 & 0.446 & -2.931 & 0.003\end{array}$

$\begin{array}{lllll}0.917 & 0.378 & 0.995 & 1.623 & 0.105\end{array}$

$\begin{array}{lllll}0.233 & 0.209 & 0.260 & -16.248 & 0.000\end{array}$

$\begin{array}{lllll}0.938 & 0.461 & 0.996 & 1.854 & 0.064\end{array}$

$\begin{array}{llll}0.003 & 0.000 & 0.045 & -4.109-0.000\end{array}$

$\begin{array}{lllll}0.089 & 0.061 & 0.130 & -10.862 & 0.000\end{array}$

$\begin{array}{lllll}0.134 & 0.073 & 0.232 & -5.449 & 0.000\end{array}$

$\begin{array}{lllll}0.146 & 0.092 & 0.223 & -6.645 & 0.000\end{array}$

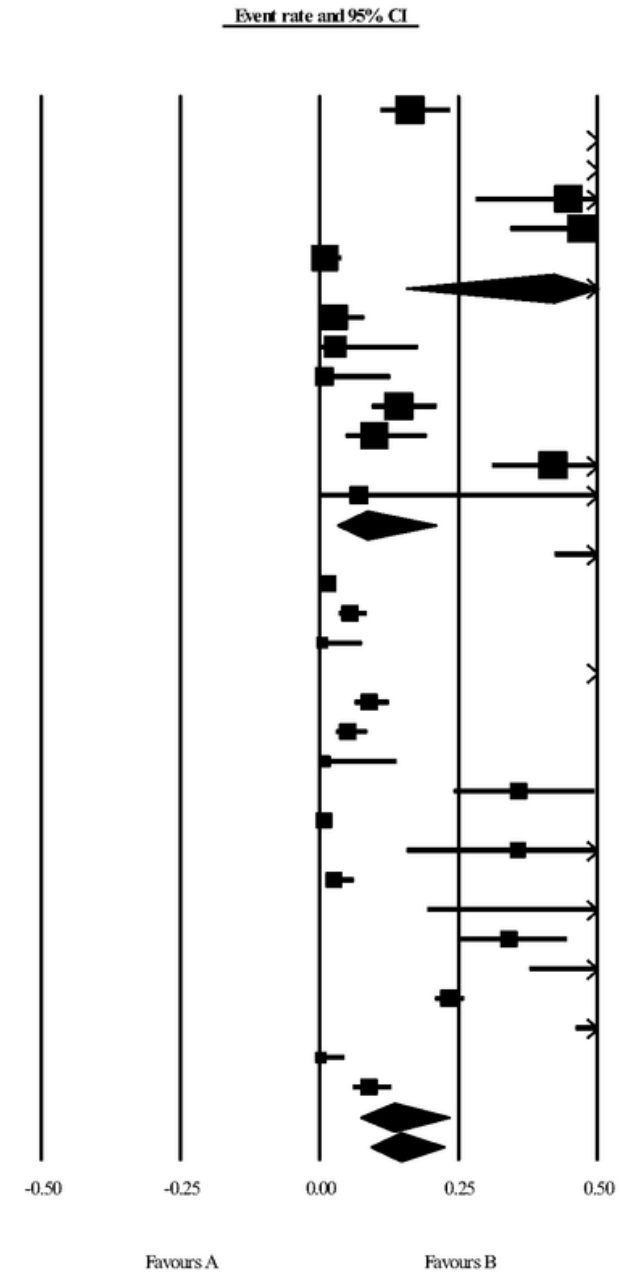

Favours A

Favours B

Figure 4

Forest plot analysis of studies in three different categories of quality assessment. The plot indicates studies with higher qualities use high-sensitive methods for the detection of NAr mutations 


\begin{tabular}{|c|c|}
\hline \multirow{2}{*}{$\begin{array}{l}\text { Groupby } \\
\text { Sulgroup witlin stucty }\end{array}$} & \multirow{2}{*}{ Sucty name } \\
\hline & \\
\hline Excellent & Bui et al 2017 \\
\hline Excellent & Coffinet al 2014 \\
\hline Excellent & Gao et al 2017 \\
\hline Excellent & Mh et al 2013 \\
\hline Excellent & Munshi et al 2017 \\
\hline Excellent & Vutien P 2013 \\
\hline \multicolumn{2}{|l|}{ Excellent } \\
\hline Good & Jard R 2007 \\
\hline Good & Lik-Yuen Chan et al 2007 \\
\hline Good & Panigrahi R 2013 \\
\hline Good & Salpini et al 2011 \\
\hline Good & Singla B 2013 \\
\hline Good & Singla et al 2015 \\
\hline Good & Widasariet al 2014 \\
\hline \multicolumn{2}{|l|}{ Good } \\
\hline Very Good & Widasariet al 2014 \\
\hline Very Good & Gomes-Gouvea et al 2015 \\
\hline Very Good & Han Y 2009 \\
\hline Very Good & Ismail AM 2010 \\
\hline Very Good & Kim et al 2017 \\
\hline Very Good & Mahabadi M 2013 \\
\hline Very Good & Mirandola et al 2011 \\
\hline Very Good & Moehlen et al 2013 \\
\hline Very Good & Mustafa ALTIND? et al 2016 \\
\hline Very Good & Nguyen MH 2009 \\
\hline Very Good & Nishij ima N 2012 \\
\hline Very Good & Pacheco et al 2017 \\
\hline Very Good & Pastor et al 2009 \\
\hline Very Good & Sayanet al 2010 \\
\hline Very Good & Solmone et al 2009 \\
\hline Very Good & Tan 2012 \\
\hline Very Good & WASTYYASTUTI et al 2016 \\
\hline Very Good & Xuet al 2015 \\
\hline Very Good & Zhoo $Y$ et al 2016 \\
\hline \multicolumn{2}{|l|}{ Very Good } \\
\hline Overall & \\
\hline
\end{tabular}

\begin{tabular}{|c|c|c|c|c|c|c|}
\hline \multirow[t]{2}{*}{ Score } & \multirow[t]{2}{*}{ Comparison } & \multirow[b]{2}{*}{$\begin{array}{c}\text { Event } \\
\text { rate }\end{array}$} & \multicolumn{3}{|c|}{ Statistics for each stuty } & \multirow[b]{2}{*}{ p-Value } \\
\hline & & & $\begin{array}{l}\text { Lower } \\
\text { limit }\end{array}$ & $\begin{array}{l}\text { Upper } \\
\text { limit }\end{array}$ & Z-Value & \\
\hline Excellent & NGS & 0.163 & 0.110 & 0.235 & -7.022 & 0.000 \\
\hline Excellent & NGS & 0.909 & 0.700 & 0.977 & 3.105 & 0.002 \\
\hline Excellent & NGS & 0.982 & 0.770 & 0.999 & 2.808 & 0.005 \\
\hline Excellent & PASS & 0.448 & 0.281 & 0.628 & -0.556 & 0.578 \\
\hline Excellent & NGS & 0.472 & 0.342 & 0.605 & -0.412 & 0.680 \\
\hline \multirow[t]{2}{*}{ Excellent } & ImoLipa & 0.010 & 0.003 & 0.039 & -6.451 & 0.000 \\
\hline & & 0.421 & 0.156 & 0.740 & -0.460 & 0.646 \\
\hline Good & Direct Seq & 0.027 & 0.009 & 0.080 & -6.122 & 0.000 \\
\hline Good & Direct Seq & 0.029 & 0.004 & 0.177 & -3.476 & 0.001 \\
\hline Good & Direct Seq & 0.009 & 0.001 & 0.127 & -3.315 & 0.001 \\
\hline Good & Direct Seq & 0.143 & 0.094 & 0.211 & -7.419 & 0.000 \\
\hline Good & Direct Seq & 0.099 & 0.048 & 0.193 & -5.559 & 0.000 \\
\hline Good & Direct Seq & 0.420 & 0.310 & 0.539 & -1.319 & 0.187 \\
\hline \multirow[t]{2}{*}{ Good } & Direct Seq & 0.071 & 0.004 & 0.577 & -1.748 & 0.081 \\
\hline & & 0.085 & 0.032 & 0.209 & -4.467 & 0.000 \\
\hline Very Good & NGS & 0.929 & 0.423 & 0.996 & 1.748 & 0.081 \\
\hline Very Good & Direct Seq & 0.016 & 0.009 & 0.028 & -13.624 & 0.000 \\
\hline Very Good & Direct Seq & 0.055 & 0.035 & 0.085 & -11.739 & 0.000 \\
\hline Very Good & Direct Seq & 0.005 & 0.000 & 0.076 & -3.719 & 0.000 \\
\hline Very Good & Direct Seq & 0.603 & 0.517 & 0.683 & 2.342 & 0.019 \\
\hline Very Good & Direct Seq & 0.089 & 0.063 & 0.125 & -11.939 & 0.000 \\
\hline Very Good & ImoLipa & 0.051 & 0.030 & 0.086 & -10.270 & 0.000 \\
\hline Very Good & ImoLipa & 0.010 & 0.001 & 0.138 & -3.247 & 0.001 \\
\hline Very Good & Direct S & 0.358 & 0.242 & 0.495 & -2.032 & 0.042 \\
\hline Very Good & Direct Seq & 0.008 & 0.003 & 0.022 & -9.484 & 0.000 \\
\hline Very Good & NGS & 0.357 & 0.157 & 0.624 & -1.054 & 0.292 \\
\hline Very Good & Direct S & 0.026 & 0.011 & 0.062 & -7.955 & 0.000 \\
\hline Very Good & Direct Seq & 0.833 & 0.194 & 0.990 & 1.039 & 0.299 \\
\hline Very Good & Direct Seq & 0.341 & 0.250 & 0.446 & -2.931 & 0.003 \\
\hline Very Good & NGS & 0.917 & 0.378 & 0.995 & 1.623 & 0.105 \\
\hline Very Good & InoLipa & 0.233 & 0.209 & 0.260 & -16.248 & 0.000 \\
\hline Very Good & NGS & 0.938 & 0.461 & 0.996 & 1.854 & 0.064 \\
\hline Very Good & DirectS & 0.003 & 0.000 & 0.045 & -4.109 & 0.000 \\
\hline \multirow[t]{3}{*}{ Very Good } & InoLipa & 0.089 & 0.061 & 0.130 & -10.862 & 0.000 \\
\hline & & 0.134 & 0.073 & 0.232 & -5.449 & 0.000 \\
\hline & & 0.146 & 0.092 & 0.223 & -6.645 & 0.000 \\
\hline
\end{tabular}

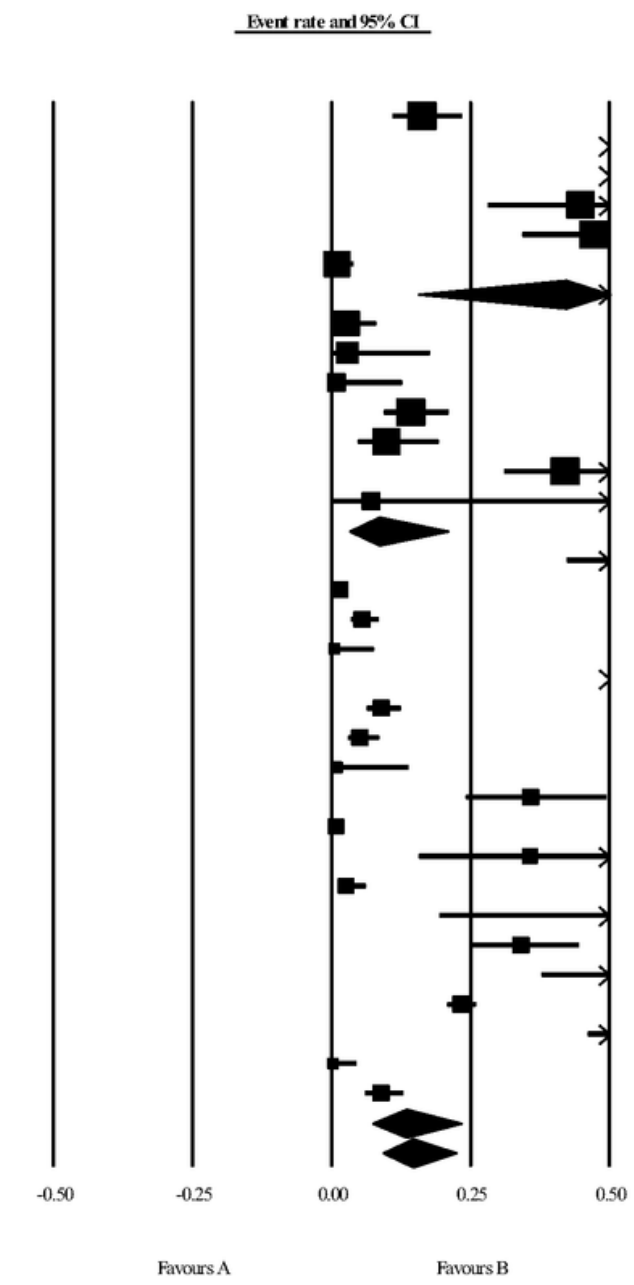

\section{Figure 5}

Forest plot analysis of studies in three different categories of quality assessment. The plot indicates studies with higher qualities use high-sensitive methods for the detection of NAr mutations

\section{Supplementary Files}

This is a list of supplementary files associated with this preprint. Click to download.

- ChecklistPRISMA2009.doc

- ChecklistPRISMA2009.doc 